\title{
Platelet-Derived Microparticle Count in $\beta$-Thalassemia Patients with Direct Labeling Monoclonal Antibody CD62P and CD41
}

\author{
Ivan Lumban Toruan, ${ }^{1}$ Pandji Irani Fianza, ${ }^{2}$ Delita Prihatni ${ }^{3}$ \\ ${ }^{1}$ Department of Internal Medicine, Dr. Soedarso Hospital, Pontianak, Indonesia, ${ }^{2}$ Division of Hematology and \\ Medical Oncology, Department of Internal Medicine, Faculty of Medicine Universitas Padjadjaran/ \\ Dr. Hasan Sadikin General Hospital Bandung, Indonesia, ${ }^{3}$ Department of Clinical Pathology Faculty of Medicine \\ Universitas Padjadjaran/Dr. Hasan Sadikin General Hospital Bandung, Indonesia
}

\begin{abstract}
Thromboembolic events are potentially life-threatening clinical complications found in $\beta$-thalassemia patients. The pathogenesis of the hypercoagulable state in $\beta$-thalassemia patients results from the degradation of excess $\alpha$-globin chains in red blood cells, leading to intracellular labile iron accumulation, oxidative stress, and more rigid, deformed, and eventually prematurely damaged red blood cells. This process is associated with the loss of the normal asymmetrical distribution of membrane phosphatidylserine and its exposure to the outer surface of the blood cell membrane resulting in the formation of tenase complexes, prothrombinase, and thrombin complexes. Increased thrombins lead to platelet activation and platelet-derived microparticles synthesis, which in turn contributes to thrombus formation. This study aimed to determine the increase in the platelet-derived microparticle count by direct labeling of CD62P and CD41 monoclonal antibodies in $\beta$-thalassemia patients when compared with normal subjects. This was a cross-sectional analytical quantitative study conducted in Dr. Hasan Sadikin General Hospital Bandung and Dharmais Cancer Hospital Jakarta Indonesia between August and September 2019. Sixty patients, divided evenly into $\beta$-thalassemia group and control group, were labeled by CD62P and CD41 monoclonal antibodies. Results showed that the $\beta$-thalassemia group had a platelet count of 197x103/uL (58-1,261) with a median count for platelet-derived microparticles of 10,553 events/uL (779$90,971)$ as opposed to 1,861 events/uL $(1,244-3,174)$ in the normal group $(\mathrm{p}<0.05)$. Therefore, the plateletderived microparticle count in the $\beta$-thalassemia patients is 5.7 times greater than in the normal subjects.
\end{abstract}

Key words: Hypercoagulation, monoclonal antibodies, phosphatidylserine, platelet-derived microparticles, thalassemia

\section{Jumlah Platelet Derived Microparticles pada Pasien Thalassemia $\beta$ dengan Metode Pelabelan Langsung Antibodi Monoklonal CD62P dan CD41}

\begin{abstract}
Abstrak
Kejadian tromboemboli berpotensi komplikasi klinis yang mengancam jiwa ditemukan pada pasien thalassemia $\beta$. Patogenesis keadaan hiperkoagulasi pada pasien thalassemia $\beta$ akibat dari degradasi rantai globin $\alpha$ berlebih dalam sel darah merah yang menghasilkan akumulasi besi labil intraseluler, dan mengarah pada stres oksidatif serta sel darah merah yang lebih kaku dan cacat, dengan akibat kerusakan prematur. Proses ini dikaitkan dengan hilangnya distribusi asimetris normal dari fosfatidilserin membran dan paparannya pada permukaan luar membran sel darah, yang meyebabkan pembentukan kompleks tenase, kompleks protrombinase dan trombin. Peningkatan trombin mengarah pada aktivasi trombosit dan sintesis platelet derived microparticles yang selanjutnya berkontribusi pada pembentukan trombus. Tujuan dari penelitian ini adalah mengetahui peningkatan jumlah platelet derived microparticles dengan metode pelabelan langsung antibodi monoklonal CD62P dan CD41 pada pasien thalassemia $\beta$ dibanding dengan subjek normal. Penelitian ini merupakan suatu penelitian kuantitatif dengan metode analitik potong lintang yang dilakukan di RSUP Dr. Hasan Sadikin Bandung dan Rumah Sakit Kanker Dharmais Jakarta antara bulan Agustus dan September 2019. Enam puluh pasien, dibagi secara merata menjadi kelompok thalassemia $\beta$ dan kelompok kontrol, diberi label oleh CD62P dan CD41 antibodi monoklonal. Hasil penelitian menunjukkan kelompok thalassemia $\beta$ memiliki jumlah trombosit 197x103/uL (58-1.261) dengan jumlah median platelet derived microparticles 10.553 partikel/uL (779-90.971) dibanding dengan 1.861 partikel/uL $(1,244-3,174)$ pada kelompok normal $(\mathrm{p}<0,05)$. Simpulan, jumlah platelet derived microparticles pada pasien thalassemia $\beta$ adalah 5,7 kali lebih besar daripada pada subjek normal.
\end{abstract}

Kata kunci: Antibodi monoklonal, fosfatidilserin, hiperkoagulasi, platelet derived microparticles, thalassemia

Corresponding Author: Ivan Lumban Toruan, Department of Internal Medicine, Dr. Soedarso Hospital Pontianak, Jalan Dr. Soedarso No. 1, Bangka Belitung Laut, Pontianak, West Kalimantan, Indonesia, Email: yastu15c@yahoo.com 


\section{Introduction}

Thalassemia is a disease caused by a partial or total deficiency of $\alpha$ or $\beta$ globin chain synthesis. This incompatible globin chain causes the globin chain to become less stable and bind to the inner membrane of red blood cells (RBC), resulting in oxidative damage responsible for membrane stiffness and increased RBC aggregation. ${ }^{1}$

The life expectancy of thalassemia patients has increased significantly over the past few years as a result of regular blood transfusions and adherence to iron chelation therapy. Nevertheless, thalassemia patients still suffer from various complications of this chronic disease. Some serious complications that were not previously described have come into light recently, one of which is thrombosis. A state of chronic hypercoagulation accompanied by activation of chronic platelets has been observed in thalassemia patients. Thrombotic disorders in thalassemia patients are manifested by clinical events such as transient ischemic attacks, arterial and venous thrombosis, pulmonary thromboembolism, pulmonary hypertension, and cerebral thrombotic events. ${ }^{2-4}$

The pathogenesis of the hypercoagulable state, especially in $\beta$-thalassemia patients, stems from the degradation of excess $\alpha$ globin chains in RBC which results in the followings: intracellular labile iron accumulation, oxidative stress, more rigid and deformed RBCs, and premature red blood cell damage. Phosphatidylserine (PS) is one of the key membrane phospholipids located along the inner side of the membrane that activates the complement pathway when expressed on the outer side of the RBC membrane, which then results in the formation of thrombin, tenase, and prothrombinase complexes. The potential of this procoagulant is strengthened by the findings of several clinical studies that show an increase in circulating erythrocyte-derived microparticles (Ery-MPs) levels in $\beta$-thalassemia patients with increased risks for thromboembolic events. ${ }^{1,5}$

The presence of PS on the outer surface of RBC thalassemia, thrombin formation, and activated platelets results in the synthesis of the platelet-derived microparticles (PMPs). Plateletderived microparticles play a crucial role in the activation of the coagulation factor of the platelets because the PMP surface procoagulant has a pro-coagulation capacity of 50-100 times higher than the platelets. The state of chronic hypercoagulation found in patients with thalassemia is evidenced by a chronic activated platelet state and an increase in PMPs that expresses several activation markers including CD62P, CD41, and other markers. ${ }^{6}$

Platelet-derived microparticles can be detected by flow cytometry examination. PMP examination currently available for patients with thalassemia is based on the 2013 International Society of Thrombosis and Hemostasis standard and aims to assess the activity and number of MPs through the binding of microparticles (MPs) with annexin $\mathrm{V}$ positive PS procoagulant, followed by re-labeling with the MPs monoclonal antibodies $(\mathrm{mAb})$ of the origin cell derivatives with a complex series of washing and centrifugation to obtain plasma pellets of PS. Specifically, MP cell derivatives originating from platelets are labeled with mAb CD62P, CD41, and other markers (CD42a, CD42b, CD61, CD63, CD107a). CD41 (GPIIb, $\alpha$ II $\beta$ integrin, fibrinogen receptors with CD61) is a very specific marker for PMPs and CD62P (P-selectin, leucocytes adhesion to endothelial) plays the role of an activated PMP marker. $^{7}$

There are several studies in which circulating MPs is measured directly in fresh blood, which is then labeled with annexin V. No washing and centrifugation are needed to avoid material loss. The sample is examined after the incubation and dilution in phosphate buffer saline (PBS), followed by labeling with specific mAb (CD62P and CD41) to identify PMPs. ${ }^{8-10}$

Researchers have not yet received reports of PMP examination through flow cytometry with fresh blood samples and direct labeling of $\mathrm{mAb}$ without annexin $\mathrm{V}$ labeling in thalassemia patients, and studies examining the count of PMPs in $\beta$-thalassemia patients as one of the hypercoagulable factors in Indonesia are scarce. This study aimed to compare the increase in the platelet-derived microparticle count by direct labeling of CD62P and CD41 monoclonal antibodies in $\beta$-thalassemia patients compared with normal individuals.

\section{Methods}

Subjects in this study consisted of $\beta$-thalassemia patients visiting the outpatient Medical Oncology Hematology clinic of Dr. Hasan Sadikin General Hospital Bandung from August to September 2019 and normal indivividuals as control. All patients and control subjects agreed to participate in the study after informed consent. The inclusion criterion used was $\beta$-thalassemia patients who were 18 years old or older and had been receiving regular blood transfusions. 
Meanwhile, the exclusion criteria used were the presence of acute episodes (infections, acute coronary syndromes, and strokes) at least one month before the study; history of anti-platelet drugs, anticoagulants, antibiotics, anti-hypertension, and anti-depressants consumption, and $\beta$-thalassemia patients who had undergone splenectomy. This study was a cross-sectional analytical quantitative study.

Thirty $\beta$-thalassemia patients and 30 normal subjects underwent blood sampling procedure. Venous blood samples were drawn from normal subjects, as well as from $\beta$-thalassemia patients shortly before blood transfusion. The amount of blood collected was $5 \mathrm{~mL}$ for every EDTAcontaining tube. Two tubes were collected from each participant. The first tube was sent and examined at the Clinical Laboratory of Dr. Hasan Sadikin General Hospital Bandung for basic hematology examination while the second tube was sent to the Clinical Laboratory of Dharmais Cancer Hospital Jakarta in less than 24 hours at room temperature $\left(20-25^{\circ} \mathrm{C}\right)$ for flow cytometry examination (BD FACS Canto II 3 laser, 8 colors, $4 \mathrm{~B} / 2 \mathrm{R} / 2 \mathrm{~V}$ configuration). Two $\mu \mathrm{L}$ of fresh blood was inserted into a Trucount tube (TruCount ${ }^{\mathrm{TM}}$ BD), added by 2 uL CD62P (anti-CD62P-PE, BD) and $10 \mathrm{uL}$ CD 41 (anti-CD41-FITC, BD). Then, PBS was added to give a final volume of $100 \mathrm{uL}$. The sample was then incubated for 30 minutes in the dark at room temperature. After incubation, the stained sample was diluted with $300 \mu \mathrm{L}$ of PBS and analyzed by flow cytometry.

Categorical data, such as those in the basic characteristics of the subjects, were presented in frequency and percentage. For numerical data, a normality test was performed first using the Shapiro Wilk test. If data were normally distributed, they were presented in mean and standard deviations. Meanwhile, data that were not normally distributed were presented in the median and range. Differences in the mean increase in the number of PMPs in $\beta$-thalassemia patients were then compared to that of the normal subjects group using the unpaired t-test if data were normally distributed and the Mann Whitney test if data were not normally distributed. Other data were obtained from the medical record of the patients. This study was approved by the Health Research Ethics Committee of Dr. Hasan Sadikin General Hospital Bandung with the ethical approval number: LB.02.01/X.6.5/213/2019.

\section{Results}

The characteristics of the subjects identified in this study were gender, age, smoking habit, frequency of transfusion, duration of

Table 1 Characteristics of Thalassemia Patients in Dr. Hasan Sadikin General Hospital in Comparison with Normal Subjects

\begin{tabular}{|c|c|c|c|}
\hline \multirow[b]{2}{*}{ Variable } & \multicolumn{2}{|c|}{ Group } & \multirow[b]{2}{*}{ p-value } \\
\hline & $\begin{array}{c}\beta \text {-Thalassemia Patient } \\
(n=30)\end{array}$ & $\begin{array}{l}\text { Normal Subject } \\
\quad(n=30)\end{array}$ & \\
\hline \multicolumn{4}{|l|}{ Gender } \\
\hline Male & $15(50.0)$ & $11(36.7)$ & \multirow{2}{*}{$0.297^{\mathrm{a}}$} \\
\hline Female & $15(50.0)$ & $19(63.3)$ & \\
\hline Age (year), median (average) & $22(18-42)$ & $21(21-27)$ & $0.940^{c}$ \\
\hline \multicolumn{4}{|l|}{ Smoking, n (\%) } \\
\hline Yes & $2(6,7)$ & $0(0,0)$ & \multirow{2}{*}{$0.492^{\mathrm{b}}$} \\
\hline No & $28(93.3)$ & $30(100.0)$ & \\
\hline \multicolumn{4}{|l|}{ Frequency of transfusion } \\
\hline Every 2 weeks & $3(10.0)$ & & \\
\hline 3 weeks & $3(10.0)$ & & \\
\hline 4 weeks & $24(80.0)$ & & \\
\hline Duration (year), mean $\pm S D$ & $19 \pm 6$ & & \\
\hline \multicolumn{4}{|l|}{ Iron chelation } \\
\hline Deferiprone & $8(26.7)$ & & \\
\hline Deferasirox & $22(73.3)$ & & \\
\hline
\end{tabular}

${ }^{\mathrm{a}}$ chi square test, ${ }^{\mathrm{b}}$ fisher exact test 
Table 2 Clinical Characteristics

\begin{tabular}{lccc}
\hline \multicolumn{1}{c}{ Variable } & \multicolumn{2}{c}{ Group } & \\
\cline { 2 - 3 } & $\begin{array}{c}\boldsymbol{\beta} \text {-Thalassemia Patient } \\
(\mathbf{n = 3 0 )}\end{array}$ & $\begin{array}{c}\text { Normal Subject } \\
(\mathbf{n = 3 0 )}\end{array}$ & p-value \\
\hline Blood pressure (mmHg) & $110(90-130)$ & $110(100-130)$ & $0.010^{*}$ \\
Systolic, median (interval) & $70(60-80)$ & $70(60-90)$ & $<0.001^{*}$ \\
Diastolic, median (interval) & $88(80-90)$ & $80(60-98)$ & $<0.001^{*}$ \\
Pulse (x/minute)), median (interval) & $151(71-178)$ & $161(152-176)$ & $<0.001^{*}$ \\
Height (cm), median (interval) & $43.5(25-60)$ & $56(43-98)$ & $<0.001^{*}$ \\
Weight (kg), median (interval) & $18.5(14.3-49.6)$ & $21.8(16.7-35.8)$ & $<0.001^{*}$ \\
IMT (kg/m $\left.{ }^{2}\right)$, median (interval) & & & \\
\hline
\end{tabular}

*analysis using the Mann Whitney test

transfusion, and iron chelation drug used for the $\beta$-thalassemia patient group and gender, age, and smoking habit for the normal subjects. Detailed subject characteristics are presented in Table 1. There were no differences in subject characteristics for gender, age, and smoking habit between the $\beta$-thalassemia patient group and the normal subjects group ( $p>0.05)$.

The clinical characteristics, i.e. blood pressure, pulse, height, weight, and BMI, in the $\beta$-thalassemia patients and normal subjects are listed in Table 2. There were differences in blood pressure, pulse, height, weight, and BMI between the $\beta$-thalassemia patients and normal subjects $(\mathrm{p}<0.05)$.
Results of the laboratory tests, i.e. hemoglobin, hematocrit, RBC, WBC, platelets, MCV, $\mathrm{MCH}$, $\mathrm{MCHC}$, and ferritin, in $\beta$-thalassemia patients and normal subjects (without ferritin values) as tested at the Clinical Laboratory of Dr. Hasan Sadikin General Hospital Bandung are presented in Table 3. Analysis of the laboratory results showed that there were differences in the median values of hemoglobin, hematocrit, RBC, platelets, $\mathrm{MCV}, \mathrm{MCH}$, and MCHC between $\beta$-thalassemia patients and normal subjects $(\mathrm{p}<0.05)$ but no difference was seen in the median WBC value between $\beta$-thalassemia patients and normal subjects $(\mathrm{p}>0.05)$.

The PMP count in $\beta$-thalassemia patients and

Table 3 Laboratory Test Results

\begin{tabular}{|c|c|c|c|}
\hline \multirow[b]{2}{*}{ Variable } & \multicolumn{2}{|c|}{ Group } & \multirow[b]{2}{*}{ P-value } \\
\hline & $\begin{array}{c}\beta \text {-Thalassemia Patient } \\
(n=30)\end{array}$ & $\begin{array}{c}\text { Normal Subject } \\
(n=30)\end{array}$ & \\
\hline Hemoglobin (g/dL), median (interval) & $7.65(5.1-12.9)$ & $13.9(10.3-17.1)$ & $<0.001^{\mathrm{b} *}$ \\
\hline Hematocrit $(\%)$, mean \pm SD & $24.4 \pm 4.8$ & $41.6 \pm 4,5$ & $<0.001^{\mathrm{a} *}$ \\
\hline $\mathrm{RBC}\left(\mathrm{x} 10^{6} / \mathrm{uL}\right)$, mean $\pm \mathrm{SD}$ & $3.38 \pm 0.76$ & $5.06 \pm 0,55$ & $<0.001^{\mathrm{a} *}$ \\
\hline WBC (/uL), median (interval) & $7,560(1,930-23,930)$ & $6,620(4,530-11,140)$ & $0.701^{\mathrm{b}}$ \\
\hline Platelet (x $\left.10^{3} / \mathrm{uL}\right)$, median (interval) & $197(58-1261)$ & $311.5(220-397)$ & $0.036^{\mathrm{b} *}$ \\
\hline MCV (fL), median (interval) & $74.05(55.8-95,2)$ & $83.8(62.4-91.2)$ & $<0.001^{\mathrm{b} *}$ \\
\hline MCH (pg), median (interval) & $23.25(17.4-32,7)$ & $28.4(19.9-31.2)$ & $<0.00^{\text {b* }}$ \\
\hline MCHC (g/dL), median (interval) & $32.25(29.1-35.1)$ & $33.75(30.6-36.7)$ & $0.019^{\mathrm{b} *}$ \\
\hline Ferritin (ug/mL), median (interval) & $3,785(1,013-9,536)$ & & \\
\hline
\end{tabular}

andependent t-test, ${ }^{\mathrm{b}}$ Mann Whitney test 
IL Toruan, et al: Platelet-Derived Microparticle Count in $\beta$-Thalassemia Patients with Direct Labeling Monoclonal Antibody CD62P and CD41

Table 4 Number of PMPs in $\beta$-thalassemia Patients Versus Normal Subjects

\begin{tabular}{lccc}
\hline \multicolumn{1}{c}{ Variable } & \multicolumn{2}{c}{ Group } & \\
\cline { 2 - 3 } & $\begin{array}{c}\boldsymbol{\beta} \text {-Thalassemia Patient } \\
(\mathbf{n = 3 0 )}\end{array}$ & $\begin{array}{c}\text { Normal Subject } \\
(\mathbf{n}=\mathbf{3 0})\end{array}$ & p-value \\
\hline $\begin{array}{l}\text { PMPs (events } / \mu \mathrm{L}) \\
\text { Median (interval) }\end{array}$ & $10,553(779-90,971)$ & $1,861(1,244-33,174)$ & $<0,001^{*}$ \\
\hline
\end{tabular}

Note: PMPs: platelet-derived microparticles

normal subjects is described in Table 4.

Analysis of the increase in PMP count in $\beta$-thalassemia patients and normal subjects group revealed a difference in PMP count median between $\beta$-thalassemia patients and normal subjects $(\mathrm{p}<0.001)$. The median PMP count in $\beta$-thalassemia patients was 10,553 events/ $\mathrm{uL}$, which was higher than in normal subjects (1,861 events/uL). The scatter result examples of the PMP count using the FCM BD FACS Canto II instrument are shown in figure $a$ and $b$, as well as the box plot graphic that shows the difference in the PMP count between the $\beta$-thalassemia group and the normal subject group.

\section{Discussion}

Many studies on PMP increase in various vascular pathologies have been published and have shown that an increase in PMPs may contribute to abnormalities in coagulation. However, not many studies measure the PMP count in thalassemia patients. PMP measurement with flow cytometry can be performed using direct labeling of specific mAb or ultra-centrifugation methods. Testing with this ultra-centrifugation method is not easy to do because it involves various laboratory tests and extensive ultracentrifugation that can affect the interpretation of the results due to the substantial loss of PMPs. Using the three-color flow cytometric technique, PMPs in peripheral blood from thalassemia patients and normal individuals can be identified and measured. Direct labeling of fresh blood and flow cytometric analysis method is a simple, fast, reproducible, and practical clinical diagnostic technic. This method also only requires a relatively small amount of blood.,14

There are a number of studies that suggested
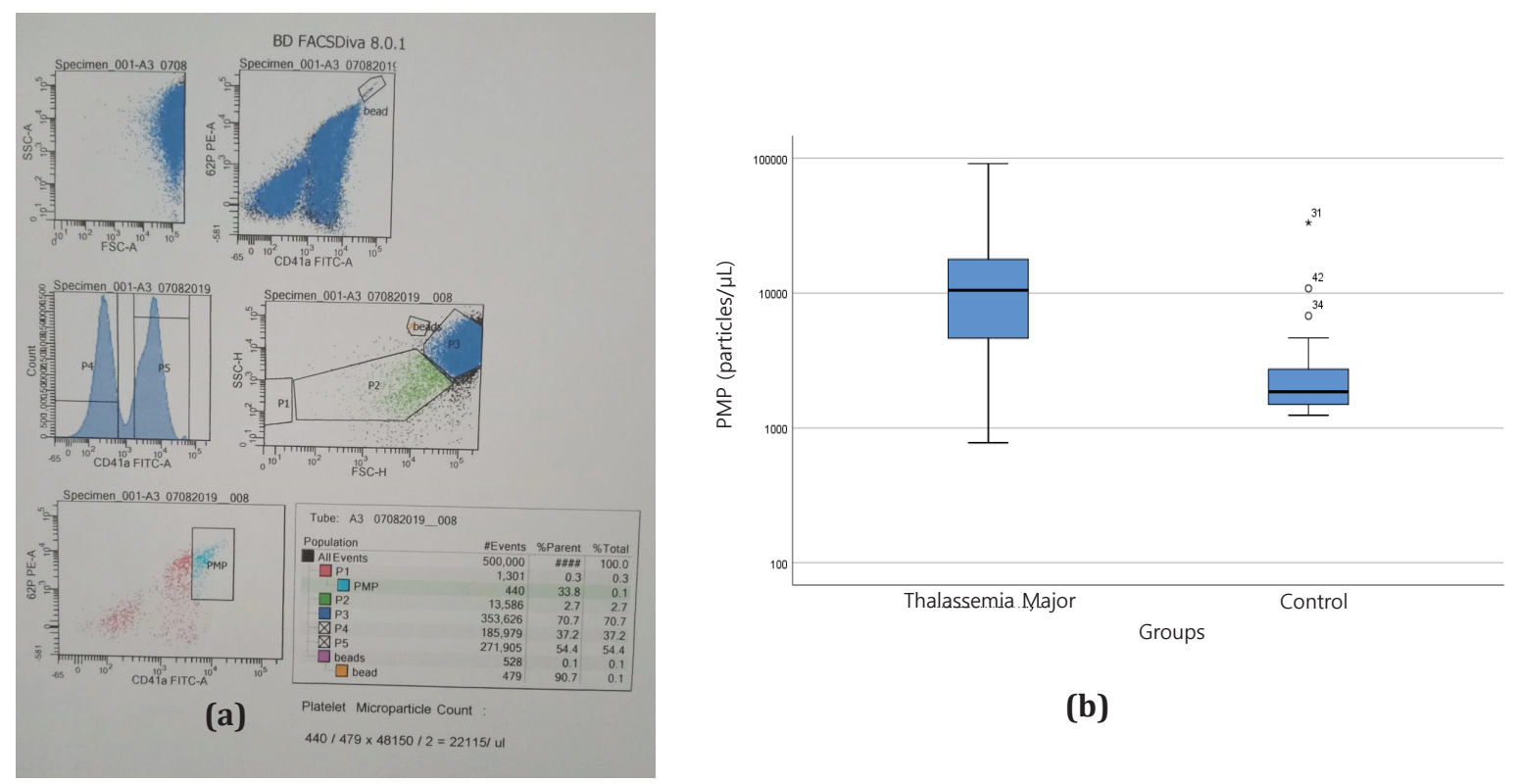

(b)

Figure (a) Example of the results of the flow cytometry examination conducted at the Clinical Laboratory of the Dharmais Cancer Hospital Jakarta. (b) The box plot graphic shows the difference in the number of PMPs between the $\beta$-thalassemia patients and the normal subject group 
platelets as the main source of PMP formation in normal individuals and in patients who are at risk for thrombosis. This is because platelets are relatively easy to be activated naturally using several mechanisms involved in their specific function in hemostasis. Abnormal RBC thalassemia with PS on the external membrane wall can increase thrombin generation in vivo and trigger platelet activation, which is then followed by the formation of PMPs. This shows that an increase in PMPs from activated platelets is a common characteristic of stressed RBC. $1,5,15,16$

Microparticles derived from activated platelets are very attractive because of their high procoagulant potential. With regards to the chronic hypercoagulation state observed in thalassemia patients, evidence suggests that platelets are in a chronically activated state with increased platelet fraction that expresses CD62P and CD63 activation markers in thalassemia patients. The data presented here clearly show that PMPs are found in blood samples of both $\beta$-thalassemia patients and normal subjects, but the $\beta$-thalassemia patients have an absolute PMP count that is much higher than normal individuals. PMPs circulating in normal individuals reflect the normal physiological balance between cell activation and aging or cell death, but can also reflect cells that can temporarily escape destruction by phagocytosis. ${ }^{11,15,16}$

Since the increase in PMPs from activated platelets can act as one of the risk factors responsible for the manifestation of hypercoagulation in thalassemia patients, PMP count can provide diagnostic or prognostic information that is useful for monitoring response to treatment. Despite its potential as a marker of a potential disease, the current assessment of the clinical relevance of PMP count is hampered by methodological problems. Prospective trials are needed to further standardize the protocol for PMP measurement, which is very important in establishing the clinical value of this marker to enable its inclusion into routine laboratory diagnostics. ${ }^{17-20}$

In conclusion, there is an increase in the number of PMPs in $\beta$-thalassemia patients by direct labeling of CD62P and CD41 mAb and that PMP count in $\beta$-thalassemia patients is 5.7 times greater than in normal individuals.

\section{References}

1. Pattanapanyasat K, Gonwong $S$, Chaichompoo P, Noulsri E, Lerdwana S, Sukapirom K, et al.
Activated platelet-derived microparticles in thalassemia. Br J Haematol. 2007;136(3): $462-71$.

2. Cappellini MD, Musallam KM, Marcon A, Taher AT. Coagulopathy in beta-thalassemia: current understanding and future perspective. Mediterr J Hematol Infect Dis. 2009;1(1):e2009029.

3. Mishra G, Saxena R, Mishra A, Tiwari A. Recent techniques for the detection of $\beta$-thalassemia: a review. J Biosens Bioelectron. 2012;3(4):1-5.

4. Trinchero A, Marchentti M, Giaccherini C, Tartari CJ, Russo L, Falanga A. Platelet haemostatic properties in $\beta$-Thalassemia: the effect of blood transfusion. Blood Transfus. 2017;15(5):413-21..

5. Agauti I, Cointe S, Robert S, Judicone C, Loundou A, Driss F, et al. Platelet and not erythrocyte microparticles are procoagulant in transfused thalassemia major patients. $\mathrm{Br}$ J Haematol. 2015;171(4):615-24.

6. Nasiri S. An overview on platelet-derived microparticles in platelet concentrates: blood collection, method preparation and storage. IJBC. 2015;7(3):119-28.

7. Ayers L, Kohler M, Harrison P, Sargent I, Dragovic R, Schaap M, et al. Measurement of circulating cell-derived microparticles by flow cytometry: sources of variability within the assay. Thromb Res. 2011;127(4):370-7.

8. Saleh HA, Kabeer BS. Microparticles: biomarkers and effectors in the cardiovascular system. Global Cardiology Science Practice. 2015;38:1-14.

9. Ismail EAR, Youssef OI. Platelet-derived microparticles and platelet function profile in children with congenital heart disease. Clin Appl Thromb Hemost. 2013;19(4):42432.

10. Bivard A, Lincz LF, Maquire J, Parsons M, Levi C. Platelet microparticles: a biomarker for recanalization in rtPA-treated ischemic stroke patients. Ann Clin Transl Neurol. 2017;4(3):175-9.

11. KheansaardW,PhongpaoK, Paiboonsukwong K, Pattanapanyasat K, Chaichompoo P, Svasti S. Microparticles from $\beta$-thalassemia/HbE patients induce endothelial cell dysfunction. Sci Rep. 2018;8(1):13033.

12. Elgammal M, Mourad Z, Sadek N, Abassy $\mathrm{H}$, Ibrahim $\mathrm{H}$. Plasma levels of soluble endothelial protein C-receptor in patients with $\beta$-thalassemia. Alexandria J Med. 2012;48:283-88.

13. Chanpeng P, Svasti S, Paiboonsukwong 
K, Smith DR, Leecharoenkiat K. Platelet proteome reveals specific proteins associated with platelet activation and the hypercoagulable state in $\beta$-thalassemia/HbE patients. Sci Rep. 2019;9(1):6059.

14. Langenskiold C, Mellgreen K, Abrahamsson J, Bemark M. Determination of blood cell subtype concentrations from frozen whole blood samples using trucount beads. Cytometry B Clin Cytom. 2018;94(4):660-6.

15. Cappellini MD, Musallam KM, Taher AT. Thalassemia as a hypercoagulable state. US Oncology Hematology. 2011;7(2):157-60.

16. Rubin O, Canellini G, Delobel J, Lion N, Tissot JD. Red blood cell microparticles: clinical relevance. Transfus Med Hemother. 2012;39(5):342-7.

17. Burger D, Schock S, Thompson CS, Montezano AC, Hakim AM, Touyz RM. Microparticles: biomarker and beyond. Clin Sci (Lond).
2013;124(7):423-41

18. Wang CC, Tseng CC, Chang HC, Huang KT, Fang WF, Chen YM, et al. Circulating microparticles are prognostic biomarkers in advanced nonsmall cell lung cancer patients. Oncotarget. 2017;8(44):75952-67.

19. Zhou BD, Guo G, Zheng LM, Zu LY, Gao W. Microparticles as novel biomarkers and therapeutic targets in coronary heart disease. Chin Med J (Engl). 2015;128(2):267-72.

20. Lacroix R, Judicone C, Mooberry M, Boucekine M, Key NS, George FD, et al. Standardization of pre-analytical variables in plasma microparticle determination: results of the International Society on Thrombosis and Haemostasis SSC Collaborative workshop [published online ahead of print, $2013 \mathrm{Apr}$ 2] [published correction appears in J Thromb Haemost. 2017 Jun;15(6):1236]. J Thromb Haemost. 2013;10.1111/jth.12207. 